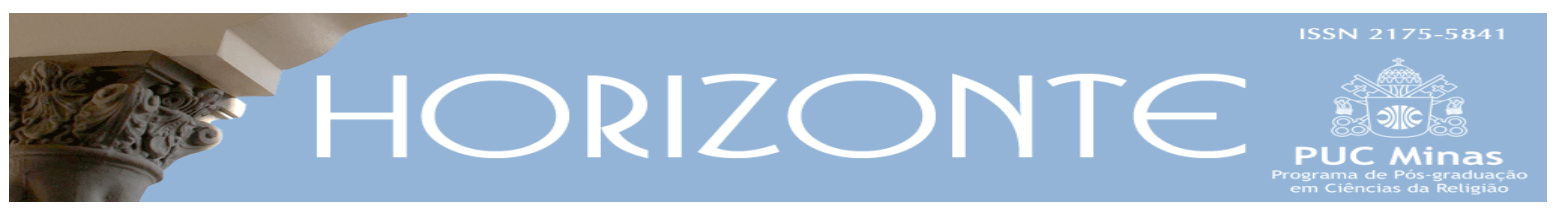

Dossiê: Conferência de Puebla: 40 anos - Artigo original (c) (1)

\title{
Catequese em Puebla: teologias em conflito
}

\author{
Catechesis in Puebla: theologies in conflict
}

Solange Maria do Carmo*

\begin{abstract}
Resumo
Desde Medellín, a catequese seguira afirmando a absoluta unidade entre a história humana e a história da salvação, pois compreendeu que é, na situação humana concreta, que Deus se revela. Em Puebla, porém, essa convicção se mostra abalada. No capítulo reservado à catequese, transparece subliminarmente um conflito de teologias, marcado pela presença de alguns paralelismos antitéticos, tais como situação humana e doutrina revelada; catequese de situação e catequese doutrinal, memorismo e ausência de memória. No saudosismo de uma catequese que não se descuide da doutrina em prol da práxis cristã, esconde-se uma tensão teológica. Nem todo o episcopado de Puebla estava convicto que os caminhos mais humanos são exatamente os mais divinos; nem todos comungavam da afirmação que Deus se diz na história humana e nela toma partido dos empobrecidos e sofredores. Por meio do estudo do Documento de Catequese (item 3 do capítulo 3 das Conclusões de Puebla), este artigo quer mostrar a coexistência de duas teologias na Conferência Episcopal Latino-americana de 1979: uma mais cristoderivada, na esteira de Medellín, que favorece a eclesiologia Povo de Deus, com valorização de todo batizado e de sua realidade cotidiana; outra, mais teoderivada, que possibilita a eclesiologia Corpo de Cristo, que compreende a Igreja como uma sociedade perfeita, hierarquicamente organizada, independente dos caminhos da humanidade.
\end{abstract}

Palavras-chave: Puebla. Catequese. Teologia. Doutrina. Eclesiologia.

\begin{abstract}
Since Medellin, catechesis has continued to affirm absolute unity between human history and the history of salvation, once it understood that God reveals himself through the concrete human situation. In Puebla, however, this conviction was shaken. In the chapter reserved for catechesis, a conflict of theologies subliminally appears, marked by the presence of some antithetical parallels, such as the human situation and revealed doctrine; situation catechesis and doctrinal catechesis, mere memorizing and absence of memory. Underlying the nostalgia of a certain catechesis that does not neglect the doctrine in favor of Christian praxis, a theological tension is hidden. No doubt, not all the whole episcopate in Puebla was convinced that the most human ways are exactly the most divine ones; not everyone shared the claim that God is manifested in human history and takes sides with the impoverished and suffering people. Through the study of the Catechesis Document, item 3 of chapter 3 of the Puebla Conclusions, this article aims to show the coexistence of two theologies at the 1979 Latin American Episcopal Conference. The first one was more Christo derivative, in the light of Medellin, that favors the People of God ecclesiology, valuing every baptized person and their daily reality; the other one was more Theo derivative, which makes possible the ecclesiology "Body of Christ", which comprehends the Church as a perfect society, hierarchically organized, independent of the ways of humanity.
\end{abstract}

Keywords: Puebla. Catechism. Theology. Doctrine. Ecclesiology.

Artigo submetido em 9 de setembro de 2019 e aprovado em 22 de dezembro de 2019.

* Doutora em Teologia pela FAJE. Professora da PUC Minas e do ISTA. País de origem: Brasil. E-mail: carmosolange@gmail.com 


\section{Introdução}

A Igreja da América Latina, movida pelo espírito do Concílio Vaticano II, vinha procurando seus próprios caminhos. Medellín (1968) fora um divisor de águas. De uma Igreja subserviente e coligada com os poderosos, passara a uma Igreja militante e combativa do lado dos sofredores. Esse posicionamento de muitos líderes eclesiais, entre eles padres, bispos, teólogos e religiosos, motivara o florescimento da Teologia da Libertação e das CEBs. Em toda a América Latina, líderes católicos eram difamados, maltratados, torturados e até mortos, por ousarem denunciar as barbáries do sistema socioeconômico que gerava "ricos cada vez mais ricos ao lado de pobres cada vez mais pobres" (JOÃO PAULO II, 1979, p. 897). Apesar das perseguições, seguia resoluta a Igreja latino-americana dando sua parcela de contribuição para a implantação do Reino de Deus.

\section{0 evento Puebla}

Depois de onze anos da Conferência de Medellín, Puebla despontava no horizonte eclesial como uma oportunidade para reafirmar as opções dos bispos latino-americanos, especialmente no que dizia respeito aos mais pobres e vulneráveis do continente. Motivados pelo compromisso firmado no Vaticano II, o pacto das Catacumbas, assinado por 40 bispos e liderado por Dom Helder Câmara, alguns bispos seguiam resolutos na opção de uma Igreja pobre ao lado dos pobres. A Igreja, representada em seus pastores, se preparava para um grande momento, vislumbrando no horizonte grandes desafios.

\subsection{Expectativas desde Medellín}

A Igreja na América Latina, depois de Medellín, havia ganhado feições próprias. As cores e os sons dos povos originários latino-americanos haviam conquistado o coração de grande parte dos prelados. As dores e lutas dessa gente foram assumidas como causas eclesiais. Seus sonhos e desejos motivavam a esperança cristã e anunciavam um novo Reino. A liturgia católica havia se 
desvestido das pompas europeias, e seus ritos e símbolos foram recriados a partir da realidade pungente dos pobres e sofredores de nosso continente. No lugar da rubrica, a expressão da vida. No lugar do canto gregoriano, o som dos tambores, da flauta de bambu e da viola sertaneja. No lugar dos paramentos sóbrios e cinzentos, vestes coloridas e alegres. No lugar de príncipes da Igreja que presidem a celebração, irmãos e companheiros de luta e de resistência que fazem comunhão de fé e vida. No lugar de catedrais góticas e santuários vistosos, choupanas de barro e de sapé, sem nenhum aparato estético, mas plenos de graça e de vida.

Às vésperas de Puebla, o povo nutria a esperança de que os bispos aprofundariam as escolhas de Medellín em direção aos pobres. O tema da pobreza seguia como questão-chave na preparação da Conferência (GUTIERREZ, 1979, p. 5). Afinal, como dissera Gustavo Gutierrez, "os pobres bateram à porta do Concílio, mas não foram atendidos"1. O que os documentos do Vaticano II trazem sobre os pobres é bem pouco. Coubera a Medellín essa tarefa em favor da Igreja do mundo, e não só da América Latina (BOFF, 1998, p. 572).

\subsection{0 conflito}

Para surpresa, porém, de grande número de católicos, leigos e clérigos, enquanto as comunidades eclesiais se dedicavam em nome da fé cristã à construção de uma terra sem males, alguns descontentes arquitetavam nos bastidores da história uma ruptura com os caminhos escolhidos em 1968 na última Conferência dos bispos latino-americanos. Amplamente divulgado na imprensa mundial foi o caso do bispo colombiano, Dom Alfonso López Trujillo², que, às vésperas de Puebla, tramava com o arcebispo de Aracaju, Dom Luciano Duarte, a próxima diretoria do CELAM (SOUZA, 1979, p. 67), prometendo-lhe firme oposição à

\footnotetext{
${ }^{1}$ Consultado por e-mail sobre essa expressão de Gustavo Gutierrez que aparece em seu artigo (BOFF, 1998, p. 572), Clodovis Boff responde: "A expressão referida do Gustavo é de oitiva. Ignoro se ele a tenha registrado em algum escrito seu" (Mensagem gentilmente cedida pelo autor).

${ }^{2} \mathrm{O}$ que aconteceu em Puebla? Um jornalista pediu uma entrevista com Lopez Trujillo, mas esqueceu a fita cassete para fazer a gravação. Então, o bispo colombiano lhe emprestou uma fita que estava à vista. Esquecera que nela estava gravada uma carta a Dom Luciano Duarte, bispo de Aracaju, na qual prometia ao arcebispado de Brasília que ele não permitiria que Puebla falasse de libertação e de teologia da libertação. $O$ jornalista, ao escutar a fita cassete, encontrou lá a carta. Não pensou duas vezes: furo jornalístico! A carta vazou para a imprensa e isso deu repercussão internacional. Sobre esse bispo e suas perversidades (MARTEL, 2019).
} 
Teologia da Libertação e à chamada "opção pelos pobres" em Puebla. Dom Trujillo criticava a teologia laical de Leonardo Boff, cujas opções teológicas ele nomeava de "opções desconcertantes" e afirmava que iria exigir um posicionamento de Roma (BETTO, 1979, p. 80-81). Pessoas como Dom Aloísio Lorscheider, Dom Paulo Evaristo Arns, Leonardo Boff, Gustavo Gutierrez etc. viram seus nomes elencados nos tribunais romanos como traidores da ortodoxia da fé. Não faltou também violência verbal e até mesmo física. Testemunhas presenciaram o bispo Trujillo agarrado ao colarinho de irmãos do episcopado ou do presbiterado, sacudindo-os com violência e gritando impropérios. Não são raras nas Conclusões de Puebla as referências que deixam ver esses conflitos internos da Igreja que, tendo optado pelos pobres e excluídos, era acusada de ser marxista. (CELAM, 1979, n. 50, 51, 903).

O enfrentamento acirrado entre duas correntes eclesiais - uma libertadora e próxima dos pobres, e outra conservadora e defensora de privilégios eclesiásticos não poderia passar incólume nos textos de Puebla. Enquanto a primeira entendia que a Igreja deveria se deixar questionar pela palavra de Deus e pela situação concreta dos empobrecidos, nos quais ela reconhecia o rosto do Senhor (GUTIERREZ, 1979, p. 5-6), a segunda desejava espiritualizar e abrandar o tema da pobreza e da radical e evangélica opção pelos pobres (GUTIERREZ, 1979, p. 6). Se a primeira insistia que a missão da Igreja é integral porque a salvação é integral, logo diz respeito não só ao espírito, mas ao homem todo, à sociedade e à história; a segunda rebatia que a missão da Igreja é essencialmente religiosa e que ela não devia se envolver com questões políticas (BOFF, 1979, p. 44).

\subsection{A resistência}

Denunciados pela corrente conservadora como traidores da fé, os teólogos da libertação foram excluídos como assessores da Conferência de Puebla (BOFF, 1979, p. 46). Mas, apesar da exclusão, lá estavam eles - mais ou menos em número de 40 - formando um verdadeiro exército, pronto a trabalhar, oferecendo in off suas contribuições para os bispos aos quais acompanhavam. Leonardo Boff, 
Clodovis Boff, João Batista Libanio, Segundo Galilea, Gustavo Gutierrez, Luis del Valle, Joseph Comblin e Henrique Dussel, juntamente com cientistas sociais e leigos engajados, faziam uma verdadeira assessoria extramuros, reconhecida pelo presidente do CELAM, Dom Aloísio Lorscheider, em entrevista à imprensa mexicana. (BOFF, 1979, p. 47).

Nas equipes de trabalho, reinava uma tensão que pesava o ambiente e dificultava a fluidez dos resultados. Não era possível escrever uma palavra sem notar claramente a disputa entre a corrente conservadora, preocupada em manter a fé nos limites estreitos da sacristia, e a corrente libertadora, decidida a deixar a força da fé fecundar a história da América Latina (BOFF, 1979, p. 45). Enquanto uns queriam uma Igreja "politicamente neutra", outros queriam-na declaradamente comprometida com as aspirações de justiça das classes populares. Numericamente, predominava o primeiro grupo, mas, qualitativamente, o segundo ganhava disparado na frente. (BETTO, 1979, p. 89). Era preciso resistir pela força do Espírito.

Pastoralistas, cujas experiências fecundas junto dos pobres se mostravam prenhes de possibilidades, não se cansavam de testemunhar a presença de Deus nos acontecidos da vida. Enquanto isso, peritos ideologicamente na retaguarda, cuja ortodoxia desconhecia a força da práxis eclesial, desconfiavam dos caminhos pastorais da Igreja. (SOUZA, 1979, p. 69). De um lado, uma Igreja triunfalista, mãe e mestra. De outro, uma Igreja mais humilde, irmã e servidora, pronta a reconhecer na sua caminhada não somente luzes, mas muita treva que precisava ser superada pelo evangelho. (SOUZA, 1979, p. 69).

\subsection{0 esforço de comunhão}

Apesar das correntes antagonistas, era preciso fazer um esforço de diálogo em nome da comunhão. Pouco a pouco, os testemunhos dos bispos engajados nas lutas populares mostraram a força libertadora da fé cristã, desarmando os mais 
conservadores. Ainda que fossem minorias, as experiências pastorais vigorosas mostravam sua potência, desconcertando os esforços que alguns faziam para preservar o modelo eclesial de séculos atrás. (SOUZA, 1982, p. 191).

O tema de Puebla, "evangelização no presente e no futuro da América Latina”, já sinalizava para que lado penderia o resultado da assembleia. Os setores tradicionais expressavam uma preocupação doutrinal, mas pouco ou quase nada tinham a dizer quando se tratava de rumos da ação evangelizadora. Seus "discursos vagos, carregados de lugares comuns, enredados em medos e cautelas." (SOUZA, 1999, p. 231) não apontavam para uma saída pastoral. Ora, desde muito, sabe-se que a Igreja não quer ser considerada apenas como centro de pensamento bem elaborado, mas como vocação missionária (SOUZA, 1982, p. 192). O tema de Puebla fazia esperançar...

O testemunho evangelizador de alguns poucos impregnou de coragem e audácia a assembleia dos prelados. Pode-se afirmar com segurança que o peso definitivo da Conferência não veio da força de convencimento dos bispos libertadores ou da habilidade dos mesmos para manobrar assembleias, mas da força das realidades ou práticas pastorais que eles testemunhavam (SOUZA, 1982, p. 191). Trata-se do poder intrínseco de convencimento de uma realidade dinâmica e fecunda (SOUZA, 1982, p. 192). Assim, pouco a pouco, o tema da libertação integral ganhou vulto e se tornou o fio condutor da mensagem teológico-pastoral da Conferência (KELLER, 2018, p. 89). Com uma costura aqui outra ali, o texto reafirmava a opção preferencial pelos pobres, o que significava grande vitória. Mas os remendos textuais mostram ao leitor habilitado "o nível médio de consciência dos bispos latino-americanos e não o nível mais avançado dentro do episcopado" (BOFF, 1979, p. 43). A duras penas, a fidelidade a Medellín estava garantida. 


\section{Documento da Catequese}

Ao afirmar que a catequese deve ser tarefa prioritária da Igreja se de fato ela quer chegar a uma nova civilização que seja participação e comunhãoª a epígrafe introdutória já avisava que havia controvérsias no Documento da Catequese.

A catequese, "que consiste na educação ordenada e progressiva da fé" (Mensagem do Sínodo da catequese, 1), deve ser ação prioritária na América Latina, se quisermos chegar a uma renovação profunda da vida cristã e portanto a uma nova civilização que seja participação e comunhão de pessoas na Igreja e na sociedade. (Epígrafe inicial).

A condicional "se" abria brecha para dois modelos catequéticos: um cuja finalidade é a participação e a comunhão na Igreja e na sociedade, e outro cuja preocupação religiosa afirma a doutrina e a moral em vez dos caminhos existenciais dos povos.

No começo, levantando os pontos positivos e negativos da caminhada desde Medellín, aparecem no Documento os chamados dualismos e falsas oposições (CELAM, 1979, n. 795), foco desde trabalho. Tomaremos aqui três deles:

\subsection{Catequese sacramental versus catequese vivencial}

Durante muitos anos, a catequese na Igreja seguira os caminhos da preparação para os sacramentos, com foco na doutrina, que era entendida como um conjunto de dogmas e normas divinamente revelados por Deus à Igreja. Trento reafirmara esse modelo com o Catecismo dos Párocos e, a esse, muitos outros se ajuntaram: Catecismos de Pedro Canísio, Catecismos de Belarmino, Catecismo Maior de Pio $\mathrm{X}$ etc. Todos eles tinham como preocupação central o ensino da doutrina. Uma catequese ao modelo de uma educação bancária ${ }^{4}$ se firmou, e a experiência cristã de Deus era dada como pressuposta pelo regime de cristandade.

${ }^{3}$ É curioso o modo como a expressão entrou no documento de Puebla (ALMEIDA, 1994, p. 26).

${ }^{4}$ Expressão cunhada por Paulo Freire. 
Numa sociedade estruturada segundo o modelo da cristandade, acreditavase que o próprio processo de socialização cultural era suficiente para a iniciação na fé. Isso fez com que o processo complexo da evangelização pudesse ser pensado como simples processo de "doutrinação, devido a uma espécie de ilusão de ótica, causada pela falta de perspectiva histórica. [...] O evangelho aparecia como dimensão óbvia e inquestionável do processo sócio-cultural 5 da época" (GOPEGUI, 1980, p. 6).

Com a chegada da modernidade, desabrochou um novo modo de compreender $\mathrm{o}$ ato catequético. A renovação catequética se expandiu na madrugada do Vaticano II. O movimento catequético cresceu e teve visibilidade, conseguindo adeptos em diversas áreas da Igreja. O Concílio, apesar de não tratar especificamente sobre a catequese, deu força a essa renovação quando olhou de modo novo a Revelação (Dei Verbum), a Igreja (Lumen Gentium) e o mundo (Gaudium et Spes). Além disso, a mudança litúrgica (Sacrosanctum Conciliun) e a abertura para a atuação do leigo e a redescoberta do seu múnus sacerdotal advindo do batismo (Apostolicam Actuositatem) fizeram com que a catequese fosse pensada não mais como lugar de doutrinar crianças e prepará-las para a primeira eucaristia e a crisma, mas como espaço propício para a transmissão da boa nova de Jesus Cristo.

Como lembra Gopegui, até o papel do catequista ganhou nova compreensão.

$\mathrm{Na}$ catequese tradicional o catequista (na grande maioria dos casos $a$ catequista) se apresentava como "porta-voz" do vigário, ou seja, como porta-voz da doutrina oficial, em poder do clero; ele deveria transmitir aos catequizandos uma série de conteúdos doutrinais, nitidamente fixados até nos pormenores da formulação, utilizando os meios pedagógicos ao seu alcance; na catequese renovada o catequista aparece como alguém que tendo internalizado de maneira pessoal a mensagem evangélica a transmite de modo criativo. (GOPEGUI, 1980, p. 4).

\footnotetext{
${ }^{5}$ Grafado assim mesmo; texto anterior ao Novo Acordo Ortográfico de 2006.
} 
Na América Latina, a Conferência de Medellín fora a primeira a embarcar nessa aventura. A leitura popular da bíblia, método amplamente difundido no Brasil pelo biblista carmelita Carlos Mesters, fora de vital importância nesse processo. A bíblia se tornou o livro base da catequese. Em vez de decorebas acerca de dogmas e preceitos, a catequese começara a ser espaço de expressão da fé dos catequizandos. Tudo que dizia respeito à vida, desde a fome, a escassez de recursos, de trabalho, de vida digna, até a festa, a dança, a alegria dos povos, tudo tinha espaço na catequese. A bíblia se tornara o humus da experiência crente, deixando de ser um instrumento para legitimar a doutrina. Sua finalidade na catequese era "permitir entrar na experiência de fé" (NAVARRO, 2007, p. 230). Compreendeu-se que Deus podia se dizer nas palavras e nas experiências humanas. O fio da vida conduzia a reflexão bíblica e a vida dos povos era entendida como um sacramento de Deus.

Os sete sacramentos foram revisitados pela catequese com os óculos da práxis cristã. Passaram a ser compreendidos como celebrações da vida. Não fazia mais sentido, então, seguir com uma catequese doutrinária cuja finalidade era a preparação para a recepção de sacramentos. A catequese pretendia superar o estigma de ser curso preparatório para os sacramentos para tornar-se oportunidade única de preparação - por meio da fé - para a vida. Dentro dessa ótica, certamente, os sacramentos não foram desprezados nem esquecidos, mas recolocados na narrativa histórica dos catequizandos.

\subsection{Situação humana versus doutrina revelada}

Com essa mudança, a centralidade de uma doutrina enrijecida não fazia mais sentido; um outro modelo catequético, o vivencial, foi conquistando os espaços disponíveis. A catequese vivencial não eliminava a doutrina, é claro, mas colocava-a no devido lugar tornando-a um caminho de fé. Mas isso não estava bem claro para grande parte dos prelados de Puebla. A centralidade na vivência da fé em todos os âmbitos do humano parecia amedrontar os mais tíbios e inseguros. 
A insistência no dualismo situação humana versus doutrina revelada (n. 795) parte da compreensão da doutrina como um conjunto de verdades reveladas diretamente de Deus à sua Igreja, fora da realidade concreta dos seus interlocutores. Opõe-se a essa compreensão, a convicção mais originária da fé cristã que afirma que "caminhar em Cristo é profissão de fé" (GOPEGUI, 1980, p. 10) e que é no caminho do seguimento que nasce a doutrina cristã (GOPEGUI, 1980, p. 10). A queixa que alguns caíram "no vivencial sem apresentação da doutrina" (n. 795) indica que, na assembleia dos bispos, ainda restava uma parcela que não assumira o discipulado como profissão de fé. No entanto, se retomamos o livro dos Atos dos Apóstolos, vemos que a comunidade nascente era chamada de Caminho e que caminhar no seguimento do Crucificado-Ressuscitado era a doutrina que os crentes assumiam como verdade. A tradição originária da fé cristã não se ampara sobre uma doutrina, mas sobre um percurso, sobre um caminho, que se delineia como doutrina. Na Carta aos Colossenses, encontra-se uma séria advertência: "Assim como recebestes a Cristo Jesus, o Senhor, assim nele andai, arraigados nele, sobre ele edificados e, apoiados na fé, como aprendestes e transbordando em ação de graças" ( $\mathrm{Cl}$ 2,6-7). Do mesmo modo, no Evangelho de Marcos, vê-se o cego Bartimeu à beira do caminho, mendicante a gritar pelo Filho de Davi. Tendo sido acolhido por Jesus que passa, o filho de Timeu não é chamado a professar a fé numa doutrina, nem lhe é fornecida uma formulação dogmática que lhe sirva de credo. Em vez disso, ele entra no caminho (Mc 10,52), pois não há profissão de fé maior que caminhar com Cristo e é assim que nasce a doutrina cristã.

Para a catequese existencial, a apresentação da doutrina só faz sentido quando subordinada à situação humana. Entende-se que a doutrina cristã não existe como um "absoluto", um dado quimicamente puro, um conteúdo conservado em formol, que deva se manter preservado da corrupção da vida do mundo. Ela é sempre relativa à caminhada no Espírito e não pode ser acorrentada em nenhuma formulação (GOPEGUI, 1980, p. 10). "Não existe $a$ doutrina cristã. Existem diversas formulações da doutrina cristã, entre as quais uma é normativa para todas as outras; a doutrina apostólica, ou seja, o conjunto dos escritos do NT" 
(GOPEGUI, 1980, p. 10). Assim, pronunciar-se sobre a questão do trabalho ou sobre a ordem política, sobre as questões que envolvem a sexualidade e a cultura dos povos, sobre temas como a educação, a saúde e o direito dos trabalhadores não é desviar-se da doutrina cristã; ao contrário, é garantir sua autenticidade. Foi assim com o povo da bíblia que, nos seus registros, não se esquivou de assuntos como a terra, a circuncisão, as prescrições alimentares, a hospitalidade e a acolhida do estrangeiro, os conflitos com as autoridades etc. Nada disso era menos importante para a comunidade eclesial que outros temas ditos espirituais, como a oração, o culto etc. Todos os problemas da época deviam ser repensados e reditos a partir da fé, assim como hoje. Tudo que diz respeito à vida diz também respeito à fé, pois não há duas histórias separadas: a história da salvação e a história do mundo. Há uma única história, que é a história humana, na qual Deus se inscreve, se diz e se auto comunica como verdade libertadora. "Se por doutrina se entende interpretação da vivência e da práxis cristã em linguagem significativa, ela se torna imprescindível no diálogo evangelizador" (GOPEGUI, 2009, p. 320), mas se é entendida como um conjunto de verdades e normas imutáveis na história, então ela pode se tornar um obstáculo para a evangelização. Como escreveu Metz, "um cristianismo preexistente à cultura e à história, um cristianismo culturalmente despido, culturalmente nu, não existe" (METZ, 1989, p.77). É bom lembrar que a multirreferencialidade e o pluralismo cultural de nossos dias exigem compromisso com o componente doutrinal do anúncio, mas ao mesmo tempo tornam esse anúncio muito mais complexo.

\subsection{Memorismo ${ }^{6}$ versus ausência de memória}

No número 795 de Puebla, aparece também uma outra queixa: a de que alguns - certamente catequistas - teriam passado do "memorismo à ausência total de memória”. Segue-se a constatação que alguns também se descuidaram da iniciação à oração e à liturgia. A nostalgia do passado parece suscitar "a tentação da volta à simplicidade dos catecismos" (GOPEGUI, 2009, p. 320), nos quais a

\footnotetext{
${ }^{6}$ Em espanhol, memorismo, e não memorizácion.
} 
decoreba tinha lugar privilegiado. A pedagogia do ensino, centrada na figura do catequista e na doutrina ensinada, havia perdido seu lugar para a pedagogia da aprendizagem, que, reconhecendo o protagonismo do catequizando, ajudava-o no árduo trabalho de construir seu conhecimento de Deus em Jesus Cristo.

\section{Como afirma Gopegui,}

Uma coisa é "ensinar" que Jesus é o Filho de Deus e outra bem diferente é colocar o homem num caminho que o leve a descobrir na figura de Jesus a figura do Filho de Deus, o Sentido e a Norma de sua própria história, através do assíduo contato com a Escritura, lida no contexto da vida (GOPEGUI, 1980, p. 16).

A catequese desde Medellín havia feito um percurso próprio, compreendendo-se não apenas com a tarefa de transmitir a doutrina por meio da assimilação de conteúdos, mas assumindo-se como caminho de encontro com Deus em Jesus Cristo, pela ação do Espírito. Nesse percurso existencial, não há lugar para a memorização, mas sim para a oração, a meditação, o canto, o símbolo, a celebração, a partilha, a reflexão e ainda para o embate, o questionamento, a ação concreta transformadora etc. Ao se dedicar à transmissão da fé por essa veia existencial, a catequese dispensa a memorização, pois ela não é mais necessária. Aprende-se e guarda-se no coração a doutrina tecida com o fio da vida. Somente aquilo que se vive, se experimenta e especialmente aquilo que se ama encontra eco no coração humano, pois, como disse Adélia Prado, "o que a memória ama fica eterno". Sai da ribalta catequética a dupla explicação-memorização e ganha protagonismo a reflexão-experimentação. $\mathrm{O}$ método dedutivo perde valor, e o indutivo fica vigoroso. A construção do conhecimento de Deus por meio de atividades pedagógicas, trabalhos em grupos e outras construções dos catequizandos ocupam o espaço antes dedicado à decoreba. A palavra de Deus lida com o fio condutor da vida possibilita o conhecimento de uma doutrina que não se decora, mas que se faz verdade no dia a dia dos catequizandos. 
O mesmo seja dito sobre a constatação que "há catequistas que descuidam da iniciação à oração e à liturgia”. A catequese depois de Medellín compreendera que havia outros modos de rezar e celebrar que não aqueles utilizados até então. A catequese pós Puebla não se descuidara da iniciação à oração ou da iniciação litúrgica, como alguns pensavam. Apenas não entendia mais que iniciar o catequizando na oração era ensinar preces prontas. Entendeu-se que orar é bem mais que recitar fórmulas decoradas, apesar de estas serem antigas e de imenso valor. Os catequistas redimensionaram os caminhos catequéticos a partir da vida e não dos catecismos. Assim, não iniciavam na liturgia ensinando o ano litúrgico, as festas e solenidades celebradas, o ritual romano com as partes da missa, mas propondo aos catequizandos verdadeiros momentos celebrativos e orantes a partir dos momentos fortes da comunidade, valorizando seus símbolos e ritos. O que estava em questão não era o desprezo pela oração ou pela liturgia, mas uma compreensão de oração e um modo de celebrar diferentes de outrora.

Ao dar espaço para a celebração da vida e para uma atitude orante alinhada com a realidade, a catequese foi criticada de descuido. Pode ter havido descuido não por descaso, mas proporcional - com um tipo de oração e um tipo de liturgia que não valorizavam a vida concreta do povo latino-americano, mas prestava-se apenas à repetição de fórmulas e ritos pouco significativos para nossa gente. Apesar de a palavra "de-colonialidade" ser recente na teologia, suas raízes vêm da práxis cristã na qual Medellin não temeu arriscar-se. Passar da oração romana à oração latino-americana, ou da liturgia romana à liturgia latino-americana, era prática teológica emancipatória que alguns bispos não viam com bons olhos, ou, nas palavras de Henrique Lima Vaz (1968), trata-se da passagem de uma "Igrejareflexo" para uma "Igreja-fonte". Ora, o Vaticano II trouxera à luz a riqueza das experiências dos povos e a necessária atualização da fé no tempo presente, por meio do tão falado aggiornamento. $\mathrm{O}$ que a catequese fazia - certamente não sem erros, é claro - era uma tentativa de aggiornare a fé cristã com a bela e rica cultura latino-americana, respondendo ao apelo do Concílio. 


\section{Conflitos teológicos}

Depois dessa análise, nota-se, pois, que duas teologias distintas coabitavam em Puebla. Dom Luciano Pedro Mendes de Almeida, então presidente da Comissão de Empalme7, não escondeu de seus agentes de pastorais e de seus pastores essa tensão. Costumava testemunhar como fora difícil a ginástica redacional de ajuntar um documento de trabalho coordenado por Lopez Trujillo com outro encabeçado por Hélder Câmara. Não poucas vezes reafirmou a importância das adversativas "mas, porém, todavia, contudo, entretanto", capazes de conectar duas ideias opostas $^{8}$. É essa coexistência de duas teologias - e consequentemente de duas eclesiologias - que se faz notar nos dualismos do texto dedicado à catequese.

\subsection{Teologia teoderivada versus teologia cristoderivada ${ }^{9}$}

Ao realçar o valor e a importância da doutrina revelada, da catequese sacramental e da memorização, uma teologia teoderivada se mostra no documento. Essa teologia compreende Jesus como porta-voz do Pai, mensageiro da revelação de Deus, como se lê no Evangelho de João: "O meu ensinamento não vem de mim mesmo, mas daquele que me enviou." (Jo 7,16).

A teologia cristoderivada, porém, compreende Jesus como a revelação de Deus, sua auto comunicação ao mundo, como também afirma o Evangelho de João, "Quem me vê, vê o Pai" (Jo 14,9). Se a primeira põe foco no mistério da criação, a segunda se debruça sobre o mistério da encarnação ou, falando de outro modo, constrói-se a partir do Jesus dos Evangelhos.

\footnotetext{
${ }^{7}$ Empalme, expressão obscura ou pouco conhecida entre nós. Sobre a expressão, Dom Luciano Mendes de Almeida admite: “Empalme que até hoje não sei traduzir bem, de engate, de encaixe, o que for, teve uma função muito grande em Puebla" (ALMEIDA, 1994, p. 26). Consultado sobre a expressão, Fernando Altemeyer Júnior diz: "Empalme é expressão em espanhol para comitê de redação. Luciano pertencia ao grupo como o foi o bispo Jorge Bergoglio em Aparecida responsável de coletar as redações parciais nas várias etapas do documento e dar uma nervatura e redação adequada de conjunto. Foi graças à sua chave de articulação em torno de duas palavras: comunhão e participação que ele ofertou uma saída para a tensão entre os grupos da Cúria e os bispos da América Latina que pretendiam seguir o sopro do Concilio e de Medellin. Era, portanto, como que o redator chefe. Empalme é o que cabe na mão" (Mensagem trocada por internet, gentilmente cedida pelo autor).

${ }^{8}$ Um pouco dessa história foi contada por $\mathrm{D}$. Luciano Mendes de Almeida num seminário sobre pastoral, realizado pelo INP (ALMEIDA, 1994, p. 27-28).

${ }_{9}^{9}$ A correlação entre a Teologia Teoderivada e a imagem de Igreja Corpo de Cristo e entre a Teologia Cristoderivada e a imagem de Igreja Povo de Deus é originalmente do catequeta francês Denis Villepelet (2009, p. 376).
} 
Numa teologia teoderivada, a questão de Deus tem centralidade. Sua onipotência, sua onisciência e sua onipresença, manifestadas no ato criador, são seus atributos mais marcantes. Trata-se de um processo dedutivo, de cima para baixo, ou do alto - onde se pensava habitar Deus - para o mundo, onde moram os pobres humanos, criaturas pecadoras, frágeis e necessitadas de conversão.

Enquanto isso, numa teologia cristoderivada, a questão central não é Deus, mas a sua manifestação histórica em Jesus de Nazaré. Um processo indutivo se delineia. Conhece-se a Deus por meio de seu Filho, o Verbo feito carne. Os atributos divinos do Pai que o Filho revela são a misericórdia, o amor, a capacidade de perdoar, a valorização da vida humana e o compromisso com os sofredores.

$\mathrm{Na}$ primeira, o ser humano é chamado à adoração, à prostração, à reverência, ao temor e, até mesmo, ao medo. O Deus onipotente, caracterizado como um juiz implacável e ou um algoz sem compaixão, exige obediência às normas, aceitação fiel da doutrina revelada, por meio do assentimento da fé sem questionamento.

Na teologia cristoderivada, a humanidade é chamada ao colo do Pai, como o filho pródigo confiante na misericórdia paternal. Passa-se do medo à confiança plena, que é própria do amor, pois Deus não é um velho barbudo que anota pecados, nem um olho indiscreto que tudo vê para punir algum deslize. Ele é um pastor que não se cansa de procurar sua ovelha perdida; ele é o Deus libertador que marcha à frente de seu povo; ele é o Pai de Jesus - nosso irmão - e, por isso, nosso Pai também. Ele é o G’oel, o protetor dos desvalidos, o Deus-amor revelado em Cristo, o Deus-libertador.

Na primeira, a revelação é tomada como uma doutrina, um ensinamento que o Filho de Deus feito homem veio transmitir ao mundo e do qual a Igreja se tornou, por ordem divina, guardiã (a fides quae). "A fides quae tem por conteúdo a verdade de Deus e do homem em um sentido absoluto e transcendente" (VILLEPELET, 
2001, p. 28). Essa doutrina rege não só a vida da Igreja, mas também deve reger a sociedade inteira, que deve viver sob a luz divina. Ela define a ética e a estética, inspira a arte e a arquitetura, regula as relações sociais e familiares, ordena a política e as manifestações culturais; enfim, dá as diretrizes culturais e sociais, ditando o comportamento de todos os homens e de todas as mulheres. Se a doutrina vem diretamente de Deus, a ética que dela advém não deve ser questionada. Tudo está dado: desde o conteúdo, a fé na qual se crê (fides quae), até o modo de crer, ou seja, a fé com a qual se crê (a fides qua).

Na segunda, porém, a revelação encontra sua plenitude no Homem de Nazaré; nele atinge seu ponto máximo de visibilidade. Em consonância com a Dei Verbum, compreende-se que "o conteúdo profundo da verdade, seja a respeito de Deus seja da salvação do homem se nos manifesta por meio dessa revelação em Cristo que é ao mesmo tempo mediador e plenitude de toda a revelação" (CONCÍlIO VATICANO II, Dei Verbum, n. 2). Para a teologia cristoderivada, "o ponto de partida para a determinação da singularidade da utilização cristã do termo 'doutrina' não pode ser outro senão Jesus Cristo, como evento sempre renovado da Palavra libertadora de Deus na história” (GOPEGUI, 1980, p. 8). Sem o processo da encarnação, a revelação de Deus seria incompleta. Entende-se que Jesus dá a conhecer o Pai, revela-o na sua mais profunda intimidade, pois ele é o Deus invisível entre os homens ( $\mathrm{Cl}$ 1,15). Vale, pois, o que afirma o Diretório Geral para a Catequese, n. 41: "o mistério de Cristo, na mensagem revelada, não é um elemento a mais, junto aos demais, mas sim o centro a partir do qual todos os demais elementos se hierarquizam e se iluminam". (CONGREGAÇÃO PARA O CLERO, 2003, n. 41). A fides quae, antes imutável e intocável, passa a ser entendida como uma mensagem que exige hermenêutica. Por consequência, a fides qua passa de obediência fiel e cega a um compromisso com o Reino trazido por Jesus de Nazaré. Ele exige, no seu seguimento, compromisso ético com os empobrecidos da sociedade, ou seja, o Mestre convida seus discípulos a tomar partido dos pequenos e vulneráveis do mundo. 


\subsection{Eclesiologia Corpo de Cristo versus eclesiologia Povo de Deus}

Uma teologia teoderivada reverbera numa eclesiologia cuja imagem mais indicada é o Corpo de Cristo (VILLEPELET, 2009, p. 344). Não o Corpo Místico de Cristo, do qual o Espírito é o guardião e guia, promotor de mudanças e gerador de boa-nova, metáfora tão difundida pelos santos padres, cujas bases são escriturísticas (cf. 1Cor 12,12-27; Rm 12,3-8; Ef 1,22-23). Mas sim o Corpo de Cristo, como sociedade perfeita ${ }^{10}$, estática, onde cada membro tem posição e função previamente definidas. Por mais que o Papa Pio XII tentasse com sua encíclica Mystici Corporis evitar a contraposição entre a Igreja espiritual e a Igreja hierárquica, seus esforços não surtiram o efeito desejado. O Corpo de Cristo continuou sendo identificado com a Igreja Romana, uma societas inaequalis hierarchica (VILLEPELET, 2009, p. 344). Essa "Igreja hierarquicamente estruturada e regulada pelo direito" (BUENO DE LA FUENTE, 2007, p. 46) se firmou especialmente depois da Reforma Protestante, com a Contrarreforma, numa tentativa inglória de salvar o que já estava perdido: a hegemonia da Igreja Católica Romana. Tal eclesiologia compreende que "nesse corpo tudo se mantém hierarquicamente e ele não pode subsistir senão em total dependência da cabeça" (VILLEPELET, 2009, p. 344), justificando assimetrias dos saberes, dos status e das funções. Neste modelo de Igreja, a instituição está acima do destino dos indivíduos. Tudo concorre para o bem comum e a identidade do grupo deve ser preservada. Cada indivíduo - com o dom que lhe é previamente dado como membro do corpo encontra sua realização e sua alegria no sucesso do corpo.

A eclesiologia que faz par com a teologia cristoderivada é bem diferente da acima referida. A imagem que mais lhe corresponde é a imagem do Povo de Deus. Essa metáfora harmoniza-se com o horizonte de sentido da modernidade e seu ethos evolucionário. Recuperada no século XX com o Vaticano II, essa imagem bíblica ganha grande relevo a ponto de se tornar a chave de leitura da eclesiologia conciliar. Para o Vaticano II, todos os batizados participam da salvação oferecida

\footnotetext{
10 "Societas perfecta, que acentua unilateralmente o aspecto institucional, exterior, jurídico da Igreja”. (MARTINA, 1996, p. 26).
} 
por Deus e fazem parte do seu povo escolhido, pois o batismo confere igual dignidade a todos os cristãos. Todos participam da mesma graça, pois foram mergulhados no mesmo mistério de Cristo. Essa concepção de povo eleito - por pura gratuidade e não por merecimento (cf. Dt 7,6-8) - remete a "uma missão especial em favor do outro" (BUENO DE LA FUENTE, 2007, p. 30) e evita a compreensão da Igreja como uma "justaposição de indivíduos olhando para Deus sem olhar para os outros" (VILLEPELET, 2009, p. 248).

Se a eclesiologia Corpo de Cristo gera passividade, conformidade e manutenção do status quo, a eclesiologia Povo de Deus empurra os cristãos para o compromisso histórico. Cada batizado é incitado a assumir seu protagonismo, a enfrentar a luta por dias melhores, a viver a fraternidade com os irmãos sob o olhar carinhoso do Pai. Se a primeira realça a assimetria das relações, a segunda põe foco na vida fraterna, na igualdade de direitos, no reconhecimento da dignidade dos batizados. A igualdade fundamental de todos os fiéis no conjunto do Povo de Deus advém do batismo, antes de qualquer hierarquização, que advém do sacramento da ordem.

Enquanto a primeira exalta a obediência, a segunda fomenta a solidariedade, pois a unidade desse povo não provém senão da confissão de fé no Deus libertador que os reúne em torno de si. A Igreja Povo de Deus aponta menos para as diferenças que constituem a eclesia e muito mais para a solidariedade que a cimenta. E, ainda que as diferenças persistam devido à organização da instituição, na Igreja Povo de Deus, a hierarquia é entendida como serviço dos membros de Cristo que se encontram unidos entre si pela mesma caridade, como afirma Paulo VI na Encíclica Evangélica Testificatio (ET, 24). Na caminhada de povo eleito, os dons trazidos por cada um e as tarefas assumidas são entendidos como serviço em defesa da vida, principalmente daquela que se encontra mais ameaçada ao longo do caminho. 
Se na primeira imagem - Corpo de Cristo - o cristão encontra-se em posição de passividade, pois seu lugar já é previamente dado, na segunda - Povo de Deus o cristão se posiciona no cenário da Igreja e do mundo como ator engajado na missão. Sua fé se mostra como um ato de decisão e de engajamento livre e refletido, enquanto que na primeira ela é uma herança familiar e social. O cristão, ator social ou agende transformador, constitui com outros irmãos a Igreja de Deus, cujo imperativo ético é vida doada em favor dos fragilizados. O papa Francisco, cuja eclesiologia do Vaticano II tem insistido em recuperar, escreve na Evangelli Gaudium: "a imensa maioria do Povo de Deus é constituída por leigos. Ao seu serviço está uma minoria: os ministros ordenados.” (FRANCISCO, 2013, p. 102).

\section{Conclusão}

Na Conferência de Puebla, duas correntes eclesiais duelam entre si. Cada uma se alimenta de uma teologia e tem seu nicho em uma eclesiologia própria. De um lado, teólogos tradicionais, catequetas e catequistas que não se deixaram impregnar pela renovação catequética, nem pelo sopro renovador do Concílio Vaticano II. De outro, teólogos dos pobres, catequetas e catequistas cujas bases fincadas no chão da história não aceitam mais a catequese doutrinária, focada em dogmas e preceitos.

De um lado, a teologia teoderivada - fundada na escolástica - conta com representantes que desejam voltar aos tempos gloriosos de uma Igreja triunfalista, hegemônica e romana, uma igreja doutrinária e autoritária. De outro, a teologia cristoderivada - representada pela Teologia da Libertação - tem ao seu lado pastores e ministros que testemunham a beleza de uma Igreja servidora, pobre e comprometida com os empobrecidos, ou seja, uma Igreja encarnada e participativa.

Onze anos depois da II Conferência Latino-americana, duas eclesiologias distintas procuram reconhecimento. Puebla, apesar das tensões, ainda prossegue na esteira de Medellín. 


\section{REFERÊNCIAS}

ALMEIDA, Luciano Mendes de. A Igreja no Brasil e Puebla. In: INSTITUTO NACIONAL DE PASTORAL (org.). Pastoral da Igreja no Brasil nos anos 7o: caminhos, experiências e dimensões. Petrópolis: Vozes, 1994. p. 21-39.

BIBLIA DE JERUSALÈM. Nova edição, revista. São Paulo: Paulinas, 1985.

BOFF, Clodovis. A originalidade histórica de Medellín. Convergência, Brasília, v. 33, n. 317, p. 568-575, 1998.

BOFF, Leonardo. Puebla: ganhos, avanços, questões emergentes. Revista Eclesiástica Brasileira, v. 39, n. 153, p. 43-63, mar. 1979.

BUENO DE LA FUENTE, Eloy. Eclesiologia. Madri: Biblioteca de Autores Cristianos, 2007.

CONCÍLIO VATICANO II. Constituição dogmática Dei Verbum. In: VIER, Frei Frederico (coord.). Compêndio do Vaticano II: constituições, decretos, declarações. Petrópolis: Vozes, 1986.

CONGREGAÇÂO PARA O CLERO. Diretório geral para a catequese. São Paulo: Paulinas, 2003.

CONSELHO EPISCOPAL LATINO-AMERICANO. Evangelização no presente e no futuro da América Latina: conclusões da Conferência de Puebla. São Paulo: Paulinas, 1979.

FRANCISCO, papa. Evangeli Gaudium. Disponível em:

https://m.vatican.va/content/dam/francesco/pdf/apost_exhortations/documents/papafrancesco_esortazione-ap_20131124_evangelii-gaudium_po.pdf. Acesso em: 9 set. 2019.

GOPEGUI, J. A. Ruiz de. A catequese após Puebla: uma reflexão teológica sobre a metodologia. Síntese Nova Fase, Belo Horizonte, v. 7, n. 18, p. 3-19, jan./abr. 1980.

GOPEGUI, J. A. Ruiz de. Catequese e experiência de Deus em Jesus Cristo. Perspectiva Teológica, Belo Horizonte, n. 41, p. 317-344, 2009.

GUTIERREZ, Gustavo. Pobres e libertação em Puebla. São Paulo: Paulinas, 1979.

JOÃO PAULO II, Papa. América Latina. Sedoc, Petrópolis, v. 11, n. 119, p. 897-898, mar. 1979.

KELLER, Miguel Ángel. A Conferência de Puebla: contexto, preparação, realização, conclusões e recepção. In: BRIGHENTI, Agenor; PASSOS, João Décio (org.). Compêndio das conferências dos bispos da América Latina e Caribe. São Paulo: Paulinas: Paulus, 2018. p. 83-93. 
MARTEL, Fréderic. No armário do Vaticano: poder, hipocrisia e homossexualidade. Rio de Janeiro: Objetiva, 2019.

MARTINA, Giacomo. História da Igreja: de Lutero a nossos dias. São Paulo: Loyola, 1996.

METZ, Johann-Baptist. Unidade e pluralismo: problemas de perspectivas da enculturação. Concilium, Petrópolis, n. 224, p. 75-83, 1989.

NAVARRO, José Maria Pérez. Por una catequesis que da la palavra a la palabra.

Catequetica, Bilbao, v. 48, n. 4, p. 228-234, 2007.

PAULO VI, Papa. Evangélica Testificatio. Petrópolis: Vozes, 1972.

SOUZA, Luiz Albert Gómez de. Classes populares e Igreja nos caminhos da história. Petrópolis: Vozes, 1982.

SOUZA, Luiz Alberto Gomez de. A caminhada de Medellín a Puebla. Perspectiva Teológica, Belo Horizonte, v. 31, n. 84, p. 223-234, 1999.

SOUZA, Luiz Alberto Gómez de. Documento de Puebla: diagnóstico a partir dos pobres. Revista Eclesiástica Brasileira, Petrópolis, v. 39, n. 153, p. 64-87, 1979.

VAZ, H. C. de L. Igreja-reflexo vs Igreja-fonte. Cadernos Brasileiros, Rio de Janeiro, n. 46, p. 17-22, abr. 1968.

VILLEPELET, Denis. Les défis de la transmission dans un monde complexe. Paris: Desclée de Brouwer, 2009.

VILLEPELET, Denis. Propos sur les paradigmes catéchètiques. Catéchése, Paris, n. 165, p. 21-44, 2001. 